Peters, Oscar; Rickes, Matthias; Jöckel, Sven; Criegern, Christian, von; Deursen, Alexander, van:

Explaining and analyzing audiences: a social cognitive approach to selectivity and media use

URN: $\quad$ urn:nbn:de:gbv:ilm1-2015210173

Published OpenAccess: January 2015

Original published in:

Communications : the European journal of communication. - Berlin [u.a.] : de Gruyter (ISSN 1613-4087). - 31 (2006) 3, S. 279-308.

DOI: $\quad$ 10.1515/COMMUN.2006.019

URL: $\quad$ http://dx.doi.org/10.1515/COMMUN.2006.019

[Visited: 2014-10-15]

„Im Rahmen der hochschulweiten Open-Access-Strategie für die Zweitveröffentlichung identifiziert durch die Universitätsbibliothek IImenau."

"Within the academic Open Access Strategy identified for deposition by Ilmenau University Library."

"Dieser Beitrag ist mit Zustimmung des Rechteinhabers aufgrund einer (DFG-geförderten) Allianz- bzw. Nationallizenz frei zugänglich."

"This publication is with permission of the rights owner freely accessible due to an Alliance licence and a national licence (funded by the DFG, German Research Foundation) respectively."

\section{DFG}

Nationallizenzen 


\title{
Explaining and analyzing audiences: A social cognitive approach to selectivity and media use
}

\author{
OSCAR PETERS, MATTHIAS RICKES, SVEN JÖCKEL, \\ CHRISTIAN VON CRIEGERN and ALEXANDER VAN DEURSEN
}

\section{Abstract}

This study explored LaRose and Eastin's (2004) model of media attendance, within a European context. It extended the uses and gratifications ( $U$ and $G$ ) paradigm within the framework of social cognitive theory (SCT) by instituting new operational measures of gratifications sought, reconstructed as outcome expectations. Although the model of media attendance offers some promising steps forward in measuring media selectivity and usage, and to some extent is applicable to another context of media use, the relative importance of outcome expectancies in explaining media usage and selectivity is not fully supported.

Keywords: media use, social cognitive theory, uses and gratifications

\section{Introduction}

One of the most prominent research approaches in communication research that focuses on media use and selectivity is the U and G approach. Although the descriptive benefits of $U$ and $G$ are very extensive and significant and may well be sufficient to account for the continued appeal of the approach (McQuail, 2001), the explaining and predicting quality of $\mathrm{U}$ and $\mathrm{G}$ for media use and selectivity is less pronounced. Also, there is criticism about the measurement and analysis of retrospective selfreported gratifications (e.g., Babrow, 1988; Messaris, 1977; Hendriks Vettehen and Van Snippenburg, 2002; Peters and Ben Allouch, 2005). Despite attempts to produce a more rigorous and comprehensive theory, several flaws continued to plague the perspective, and $\mathrm{U}$ and $\mathrm{G}$ fell out of favor with some mass communication scholars for several decades (Ruggiero, 2000). The arrival of new media (especially the Internet) and new uses of existing media have been a stimulus to research, and one of the strengths of the $\mathrm{U}$ and $\mathrm{G}$ approach came into its own - the capacity 
for comparative analysis of the appeal - for different audiences (McQuail, 2001).

Early $U$ and $G$ researchers tried to explain media use by inventorying the consequences of media use that people experienced. These experienced gratifications were used to explain media use. Typical for these gratifications is that the gratifications are the result of media use. Here lies one of the main criticisms of $U$ and $G$, namely that media use is explained by the consequences it has for the user. According to Hendriks Vettehen (1998), a circular argument seemed to have been used: Use leads to desired gratifications, but the desire to receive these gratifications is also the reason for use. A number of media scholars (e. g., Katz, Blumler, and Gurevitch, 1974) stressed the need to distinguish between the motives for media consumption and the gratifications perceived from this experience. Greenberg (1974) is one of the first authors who separated the concept gratification into two different concepts, namely 'gratifications sought' and 'gratifications obtained'. Rosegren (1974) introduced a similar distinction as he called gratification sought 'motives', and instead of gratifications obtained he used the concept 'evaluation'. With the division of the general concept gratification into the concept of motives followed by media use and the concept evaluation after media use, there was no longer a circular argument to explain media use (Hendriks Vettehen, 1998). By the division of gratification into the two concepts, it is now theoretically possible to explain the changes in media use and selectivity by the discrepancy between gratifications sought (motives) and gratifications obtained (evaluation). Unfortunately, several studies have shown that the central concept motive is not distinguishable from concrete behavior and its social or mental background. Lometti, Reeves, and Bybee (1977) suggested that it is not possible to isolate gratifications sought and gratifications obtained on an empirical level. According to LaRose et al. (2001), attempts made by U and $G$ researchers (e. g., Babrow and Swanson, 1988) to distinguish gratifications from formulations involving outcome expectations were to no avail and failed to produce more robust explanations of media exposure.

\section{Media use and selectivity and social cognitive theory (SCT)}

According to LaRose, Mastro, and Eastin (2001), the gratifications sought-gratifications obtained formulation is seemingly indistinguishable from an important mechanism in SCT (Bandura, 1986); i. e., enactive learning. Enactive learning describes how humans learn from experience. In the social-cognitive view, interactions with the environment influence media exposure by continually reforming expectations about the likely outcomes of future media consumption behavior. Seemingly, 
this represents the same process that describes the relationship among gratifications sought, media behavior, and gratifications obtained (Palmgreen, Wenner, and Rosegren, 1985). According to LaRose et al. (2001), the outcome expectation construct parsimoniously bridges the gulf between gratifications sought and gratifications obtained in $U$ and $G$ research.

According to Stone (1998), SCT stems from social learning theory, which has a rich historical background dating back to the late 1800s. Its early foundation was laid by behavioral and social psychologists, and it evolved under the umbrella of behaviorism. Within SCT, human behavior is defined as a triadic, dynamic, and reciprocal interaction of personal factors, behavior, and the environment (Bandura, 1986). The triadic causal mechanism is mediated by symbolizing capabilities that transform sensory experiences into cognitive models that guide actions. While there are several versions of SCT to which researchers currently subscribe (Stone, 1998), they all share three basic tenets: a) response consequences (such as rewards or punishments) influence the likelihood that a person will perform a particular behavior again in a given situation (enactive learning); b) humans can learn by observing others (vicarious learning) in addition to learning by participating in an act personally; and c) individuals are most likely to model behavior observed by others they identify with.

The comprehensiveness and complexity of the SCT make it somewhat difficult to operationalize, and many applications of SCT focus on one or two constructs, such as self-efficacy (e.g., Hofstetter, Zuniga, and Dozier, 2001), while ignoring the others (Stone, 1998). Although SCT is a broad theory of human behavior, it has also been applied to media use and selectivity (e. g., Bandura, 2002).

\section{A new model of media attendance}

The results of an empirical study by Larose and Eastin (2004) to test a new model of media attendance within the framework of SCT both affirm the U and G paradigm according to Larose and Eastin (2004) and extend it to a theory of media attendance grounded in SCT. By instituting new operational measures of expected gratifications, it was possible, according to Larose and Eastin (2004), to predict media consumption to an unprecedented degree, and new variables from SCT improved the explanatory power of gratifications, reconstructed as outcome expectations. According to LaRose and Eastin (2004), outcome expectations reflect current beliefs about the outcomes of prospective future behavior, but are predicated on comparisons between expected incentives and incentives attained in the past. Outcome expectations, defined as judgments of the likely consequences of behavior (Bandura, 1997), provide 
incentives for enacting behavior, while expectations of aversive outcomes provide disincentives (Bandura, 1986). According to LaRose et al. (2001), food, drink, and physical contact are primary incentives that motivate human behavior from infancy, but adults respond to symbolic incentives as well. These include monetary incentives, social incentives (such as obtaining approval from others), and status incentives. Sensory incentives involve exposure to pleasing or novel sensations. Preferences for enjoyable activities are the basis for activity incentives. There are also internal, self-reactive incentives resulting from comparisons of personal actions with standards for behavior.

However, according to LaRose and Eastin (2004), expectations are also shaped by vicarious learning, based on observations of the experiences of others. Another important determinant of behavior according to LaRose and Eastin (2004) is self-efficacy, or belief in one's capability to organize and execute a particular course of action (Bandura, 1997). Those who perceive themselves to be highly efficacious with reference to a particular task will invest sufficient levels of effort to achieve successful outcomes, whereas those with low levels of self-efficacy will not persist. According to LaRose and Eastin (2004), humans also possess a selfregulatory capability that provides the basis for purposive action through the subfunctions of self-monitoring, judgmental process, and self-reaction (Bandura, 1986, 1991). Self-monitoring is the observation of one's own actions to provide diagnostic information about the impact of behavior on the self, others, and the environment (Bandura, 1991). The judgmental process compares self-observations of behavior to personal standards, personal or social norms, and the valuation of the activity, particularly when the locus of control for the behavior resides in the individual. The self-reactive function supplies the behavioral incentive through the satisfaction derived from accomplishing an activity that meets desired standards (LaRose and Eastin, 2004). Also, habit strength and deficient self-regulation are expected to influence ongoing behavior. According to LaRose and Eastin (2004), repetition makes us inattentive to the reasoning behind our media behavior; our mind no longer devotes attention resources to evaluating it, freeing itself for more important decisions. Habit should be causally determined by outcome expectations, which precede habit in time. Habit strength should be preceded by selfefficacy, since users are unlikely to be inattentive to behavior they are still mastering. LaRose and Eastin (2004) defined deficient self-regulation as a state in which conscious self-control is diminished. Although habit and deficient self-regulation have not been clearly empirically distinguished in prior research, LaRose, Lin, and Eastin (2003) proposed a possible theoretical distinction, where habit represents the failure of selfmonitoring, and deficient self-regulation represents a failure of the judg- 
mental and self-reactive subfunctions. According to LaRose and Eastin (2004), deficient self-regulation reflects a state of mind distinct from one in which media consumers are inattentive, explaining how both might have independent effects on media attendance. Habit strength and deficient self-regulation should be related by the fact that persons with deficient self-control may also be expected to engage in habitual behavior (LaRose and Eastin, 2004).

\section{Examination of the new model of media attendance within a European context}

To empirically examine the strength of the new model of media attendance within a European context, a replication of the original study by Larose and Eastin (2004) on Internet usage should first be undertaken, to validate the new model of media attendance to confirm the proposed connection between $\mathrm{U}$ and $\mathrm{G}$ and SCT within a European context.

Because a single test of a newly introduced model is more likely to be successful due to the proximity of the postulated hypothesis of the proposed model to the empirical base, more stringent follow-up tests are needed. According to Popper (1989: 214), a single test is not sufficient to state the degree of corroboration; successful tests in other contexts will raise the degree of corroboration. Otherwise a situation will occur that resembles a Sisyphos-Strategy (Opp, 2002: 206), where the number of isolated models that belong together will increase, but nothing can be said about their degree of corroboration. To also test the merits of the new model of media attendance when applied to a different context of media use, other than the Internet, a second study should be undertaken to examine whether instituting new operational measures of expected gratifications also predict media consumption to an unprecedented degree in a different context of media use. The joint findings of both studies should indicate whether the proposed value of the new variables from SCT improve the explanatory power of gratifications, reconstructed as outcome expectations.

\section{A replication of the model of media attendance within a German context}

To examine the new model of media attendance (LaRose and Eastin, 2004) within a European context, a replication of the original study by Larose and Eastin (2004) on Internet usage was undertaken to validate the new model of media attendance. 


\section{Method: Sample and procedures}

In order to validate the model of LaRose and Eastin (2004), a test of the complete model was carried out among German Internet users. The survey was posted on www.psychologie-onlineforschung.de and www.wlab.de, and users of these websites were asked to take part in the survey. A sample of $n=179$ completed questionnaires was achieved. Because of the self-selection and the special focus of the websites on scholars and students, the sample was not representative for all Internet users. However, representativeness was not required as we followed a deductive research strategy. The model is considered universally valid for all Internet users and should therefore describe any subgroup too. The sample consisted of $62.6 \%$ female and $37.4 \%$ male Internet users. Age ranged from 21 to 66 years. The mean age was $32.51(S D=9.47)$. The estimation of factor loadings and path coefficients was based on unweighted least squares (ULS), because there were no normal distributions of variables and ULS was recommended for the sample size. The estimation was executed with AMOS 5.0.

The criteria for testing the structural equation model stemmed from the advanced test program after Fritz (1992). The global criteria for model fit are Goodness of Fit Index $(G F I>.90)$, Adjusted Goodnes of Fit Index $(A G F I>.90)$, and Root Mean Square Residual $(R M R<.10)$. Because of the non-normal distribution of the sample, the Normed Fit Index $(N F I>90)$ was applied instead of the ratio between chi-square and degrees of freedom $\left(\chi^{2} / d F \leq 5.00\right)$. Beside indicator reliability $\left(\rho_{x i}>.40\right)$, reliability of construct $\left(\rho_{c}>.60\right)$, average explained variance portion $\left(\rho_{\bar{v}}>.50\right)$, and convergence validity $\left(M^{2}>.40\right)$ were applied as local measures. The overall judgement of the model was based on both global and local criteria after Fritz (1992), see Table 1. As final criteria, the nomological validity would be applied when the coefficients of the estimated parameters complied with the theoretical assumptions (Fritz, 1992: 138).

Most items were derived from the original study (LaRose and Eastin, 2004). As result of a pre-test $(n=10)$, some new items were used because

Table 1. Criteria for rejection or acceptance of structural equation models.

\begin{tabular}{|c|c|c|c|}
\hline & & \multicolumn{2}{|l|}{ Global measures } \\
\hline & & Completely satisfied & Not completely satisfied \\
\hline \multirow{3}{*}{ 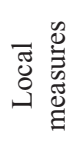 } & Completely satisfied & Acceptance & Rejection \\
\hline & $\begin{array}{l}\text { Predominantly satisfied } \\
\text { (more than } 50 \% \text { ) }\end{array}$ & $\begin{array}{l}\text { Acceptance under } \\
\text { reserve }\end{array}$ & Rejection \\
\hline & Predominantly not satisfied & Rejection & Rejection \\
\hline
\end{tabular}


they captured the German language better ${ }^{1}$. Expected outcomes, selfefficacy, habit strength, and deficient self-regulation were measured on seven-point scales. Internet usage was measured by the sum of two items; i. e., average usage on a typical weekday and average usage on a typical weekend day. Previous Internet experience was measured in years with one item. All measurement items are reported in additional Tables 1 and 2 (see Appendix). These tables also show a direct comparison of the original items with the items used in the present study.

\section{Validation of the measuring model}

First, a confirmatory factor analysis $\left(1^{\text {st }}\right.$ order) was run to test the structure of expected Internet outcomes. According to SCT, sensory feedbacks determine human behavior as behavioral outcomes. News and changes amplify, and in contrast, iteration of events attenuates sensory perception (Bandura, 1986: 233). Pertaining to media use, sensory feedback is conceptualized as novel outcomes (LaRose and Eastin, 2004: 370). Cronbach's alpha for the construct of novel outcomes based on four indicators was .72. Reliability of the first item 'get immediate knowledge of important news' (.24) was too low, but elimination based on item-tototal correlation would decrease alpha. The average explained variance portion (.39) was below the set point value. The reliability of the construct (.72) meets the criteria (Bagozzi and Yi, 1988: 17).

Also, the pursuit of interaction and integration into social groups determines media use, which provides social outcomes (Bandura, 1986: 235). The social outcomes construct was measured based on five indicators $(\alpha=.84)$. Reliability of the construct (.84) and the average explained variance portion (.53) both met the criteria. The reliability of item 'Maintain a relationship you value' (.36) was below set point value. In contrast to LaRose and Eastin's (2004) study, the item 'Get support from others' was not used because it refers more to support benefits than specifically to social outcomes. Likewise, the item 'Find others who respect my views' was not used because it is too close to measurement of status outcomes.

Often, media use is driven by the pursuit of fun and entertainment. Corresponding incentives are activity outcomes (Bandura, 1986: 236), which were measured based on four indicators $(\alpha=.88)$. In contrast to the original study, the items $\mathrm{x}_{12}$ and $\mathrm{x}_{13}$ were formulated as activity outcomes instead of activities (see additional table 1). Reliability of the construct (.88) and the average explained variance portion (.66) both met the criteria.

In SCT perspective, monetary outcomes are important incentives for human action and especially media use. In the present study, a wider 
concept was used for operationalization than in the LaRose and Eastin (2004) study. Instead of the exclusive focus on monetary shopping benefits, the five measurement items also referred to saving time and money when searching for information. Item 'Find bargains on products and services' and item 'Save time shopping' were eliminated based on itemto-total correlation because of insufficient Cronbach's alpha (.66). The alpha for the remaining three items was .73. The average explained variance portion (.49) was only marginally below the set point value. Reliability of construct (.74) meets the criteria. There was a difference between the two deleted items and the remaining items. The deleted items were explicitly related to monetary shopping benefits. In contrast, the remaining items were related to benefits from saving efforts (time and money) when searching for information.

Self-reactive outcomes refer to human self-regulatory capability. Differences between personal dispositions and individual internal standards cause behavior to compensate these differences. Results of such behavior are, for example, reductions of boredom or stress (LaRose and Eastin, 2004: 370). The construct of self-reactive outcomes was measured based on six indicators $(\alpha=.88)$. Construct reliability (.88) and average explained variance portion (.55) both met the criteria.

Individuals aspire to status and personal acceptance within social groups associated with the feeling of might. The corresponding construct of status outcomes was measured based on five indicators. Status items $\mathrm{x}_{27}-\mathrm{x}_{29}$ were rephrased with a stronger focus on status. As can be seen in additional table 1, the items used by LaRose and Eastin do not provide a substantial distance to items of social outcomes. Item 'Get up to date with technologies' was eliminated based on item-to-total correlation to improve alpha. Cronbach's alpha for the construct based on the four remaining items was .88 , and the average explained variance portion (.64) and the construct reliability (.87) were above aspiration level. Additionally, convergence validity $M^{2}$ (.44) of the complete measurement model was sufficient (Fornell, Tellis, and Zinkhan, 1982: 406).

In sum, most of the listed local criteria of the measurement model were sufficient (see additional table 3). A special focus should be placed on discriminant validity. Table 2 shows that correlations between novel and monetary outcomes $(r=.97)$ and between social and status outcomes $(r=.99)$ were very high.

Obviously, the criterion of discriminant validity (Fornell et al., 1982: 406) was violated. But there is a substantial relationship between social and status outcomes considering the high correlation. Only, status outcomes will be derived through social contacts, for example, when using a chat or forum. Parts of the high correlation between novel and monetary outcomes possibly resulted from the elimination of the special shopping 
Table 2. Correlations between expected outcomes of Internet usage.

\begin{tabular}{|c|c|c|c|c|c|c|}
\hline & 1 & 2 & 3 & 4 & 5 & 6 \\
\hline \multicolumn{7}{|l|}{ Activity } \\
\hline Monetary & .54 & & & & & \\
\hline Novel & .60 & .97 & & & & \\
\hline Social & .64 & .32 & .50 & & & \\
\hline Self-reactive & .84 & .29 & .37 & .76 & & \\
\hline Status & .61 & .31 & .46 & .99 & .70 & \\
\hline
\end{tabular}

Table 3. Global measures of the measuring model ( $1^{\text {st }}$ order $)$.

\begin{tabular}{lll}
\hline Global measures & Aspiration level & Level in model \\
\hline Global Fit Index & GFI $>.90$ & GFI $=.974$ \\
Adjusted Global Fit Index & AGFI $>.90$ & AGFI $=.967$ \\
Normed Fit Index & NFI $>.90$ & NFI $=.967$ \\
Root Mean Square Residual & RMR $<.10$ & RMR $=.070$ \\
\hline
\end{tabular}

items. The remaining items measured saving efforts (time and money) when searching for information without a special focus on shopping. However, there was no need for the elimination of monetary and status outcomes. Simultaneous existence of different outcomes (or gratifications in terminology of $\mathrm{U}$ and $\mathrm{G}$ ) is compliant with both SCT and $\mathrm{U}$ and $\mathrm{G}$. Based on the global measures, the outcome structure could not be rejected. Table 3 shows the global fit-indices for the measurement model.

Based on global and local criteria, the measurement model was 'accepted under reserve' for the sample (Fritz, 1992: 143). Therefore, a test of the complete model was acceptable. Also, the sample size was sufficient for testing the complete model (Backhaus, 2003: 365).

\section{Validation of the structural model}

The results obtained via unweighted least squares estimation showed that none of the global measures was violated. The model showed an acceptable match, see Table 4. Most of the local measures showed a sufficient level of reliability and validity.

The reliability and validity of expected outcomes did not change significantly (see additional table 4). As described in the introduction, media use is also partially determined by habitualization, self-efficacy, and deficient self-regulation. Measurement of habit strength based on three 
Table 4. Global measures of the complete model.

\begin{tabular}{lll}
\hline Global measures & Aspiration level & Level in model \\
\hline Global Fit Index & GFI $>.90$ & GFI $=.934$ \\
Adjusted Global Fit Index & AGFI $>.90$ & AGFI $=.925$ \\
Normed Fit Index & NFI $>.90$ & NFI $=.916$ \\
Root Mean Square Residual & RMR $<.10$ & RMR $=.088$ \\
\hline
\end{tabular}

indicators $(\alpha=.73)$ showed sufficient indicator reliabilities. Construct reliability (.72) was above set point value. Average explained variance portion (.47) was slightly below the aspiration level. Measurement of self-efficacy based on five indicators $(\alpha=.91)$ met the criteria. Construct reliability (.92) and average explained variance portion (.69) were above set point value. Internet deficient self-regulation was measured via four items $(\alpha=.76)$. The items used differed from the original items because a pre-test showed that the original items carried negative connotations and participants did not feel up to giving valid answers. After analysis, item 'I have tried to cut down on the amount of time I spend online but it is difficult' showed an insufficient reliability (.22). However, construct reliability (.80) and average explained variance portion (.51) both met the criteria. Additionally, convergence validity $M^{2}(.44)$ of the complete model was sufficient.

In sum, the complete model (see Figure 1) was confirmed with an acceptable fit for the analyzed sample (Fritz, 1992: 143). Therefore, an interpretation of the posited structural model and its hypotheses was possible. The following hypotheses were taken from the original study (LaRose and Eastin, 2004: 364-66). Additionally, all hypothesized relations are positively defined.

H1: Internet self-efficacy will be directly related to Internet usage

$\mathrm{H} 2$ : Internet habit strength will be directly related to Internet usage

H3: Deficient Internet self-regulation will be directly related to Internet usage

H4: Deficient Internet self-regulation will be directly related to Internet habit strength

H5: Internet self-efficacy will be directly related to Internet habit strength

H6: Prior Internet experience will be directly related to Internet self-efficacy

H7: Prior Internet experience will be directly related to Internet habit strength 


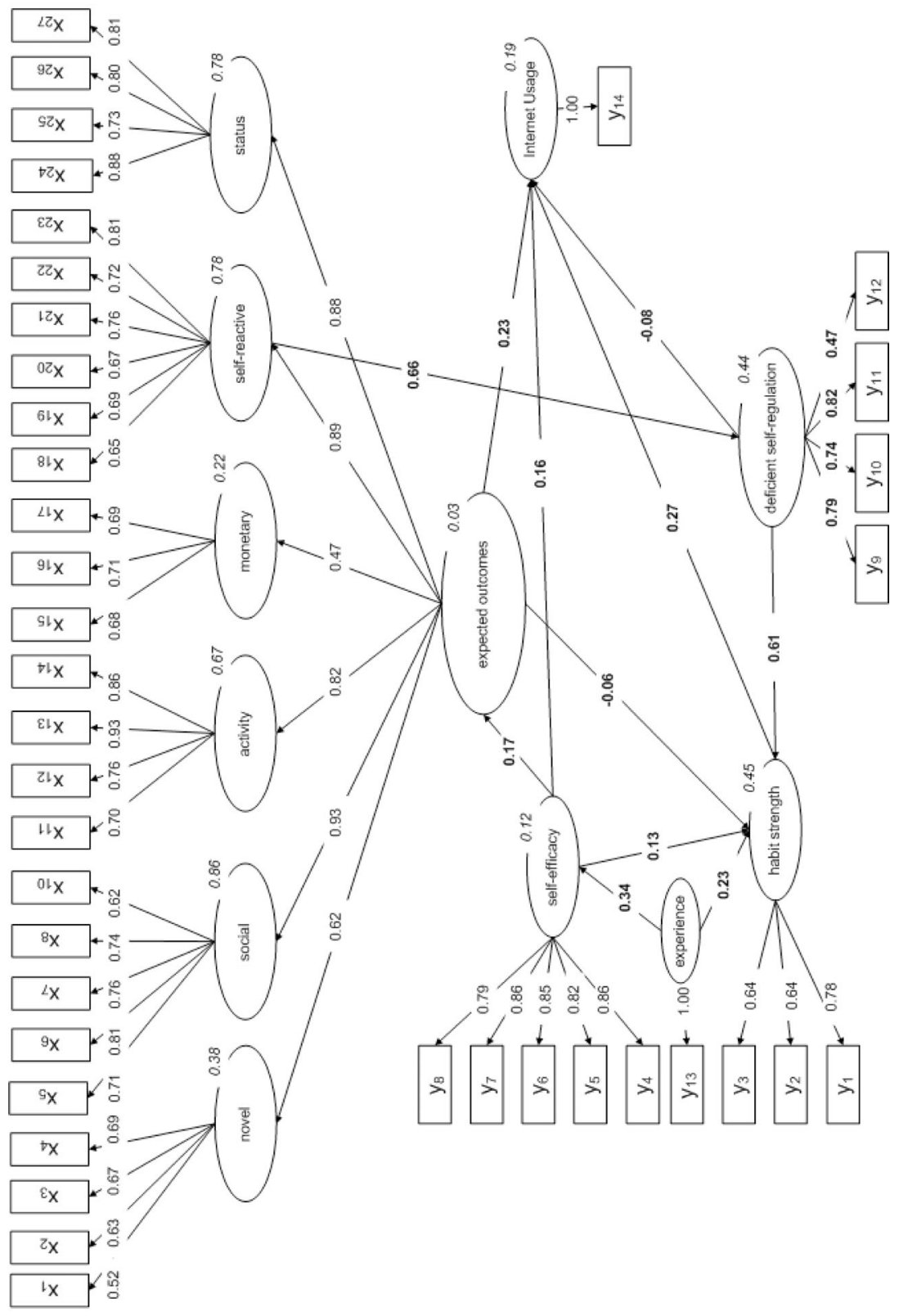

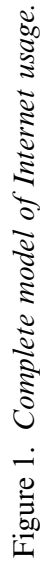


H8: Expected Internet outcomes will be directly related to Internet usage

H9: Internet self-efficacy will be directly related to expected Internet outcomes

H10: Expected Internet outcomes will be directly related to Internet habit strength

H11: Self-reactive outcomes of Internet usage will be positively related to deficient Internet self-regulation

The hypotheses refer only to the direct causal relationships between constructs. Multivariate causal structure also includes indirect effects. Therefore, the standardized indirect effects between the constructs are additionally described in the following section.

\section{Results}

The direct effect of Internet self-efficacy on Internet usage (H1) was supported (standardized regression weight equals .16). Indirect effect (.08) was only marginal. According to $\mathrm{H} 2$, there is a direct (.27) but no indirect effect (.00) of Internet habit strength on Internet usage. The estimated direct effect $(-.08)$ of deficient Internet self-regulation on Internet usage did not match the causal relationship posited in H3. Albeit marginal, in contrast to the original model, the effect was negative. Also, there was a small indirect effect (.16). In sum, the endogenous variables self-efficacy and habit strength were direct predictors of Internet usage. The direct effects found were very similar to the LaRose and Eastin (2004) findings (.15 and .26). In contrast, the connection between deficient self-regulation and Internet usage was not supported by the data in the present study.

The posited direct effect of deficient Internet self-regulation on habit strength in $\mathrm{H} 4$ was fully provided through data (.61), but there was no indirect effect (.00). The direct effect of Internet self-efficacy on habit strength (.13) provided H5. In the original study this direct effect was not significant, although it was theoretically expected. The indirect effect (.05) in the present study was only marginal and in contradiction to the assumption that self-efficacy determines habit strength mediated through expected outcomes (LaRose and Eastin, 2004: 373).

There was a direct effect (.34) of prior Internet experience on selfefficacy (H6) but no indirect effect (.00). The direct effect was very similar to the original study (.38). Prior Internet experience also determined habit strength (H7) with a direct effect (.23); the indirect effect on habit strength (.06) was only marginal. 
According to the core assumption of $\mathrm{U}$ and $\mathrm{G}$, a direct effect (.23) of expected outcomes on Internet usage was found, which supported $\mathrm{H} 8$ (.43 in the original study). The indirect effect (.03) was only marginal. Expected outcomes were partially determined through self-efficacy. Internet users with high levels of self-efficacy were more capable of organizing and executing a particular course of action than Internet users with low levels of self-efficacy. A direct effect of self-efficacy (.17) on expected outcomes supported H9 but there was no indirect effect (.00).

The estimated direct effect $(-.06)$ of expected outcomes on habit strength did not support the causal relationship posited in H10. Albeit only marginal, in contrast to $\mathrm{H} 10$ and also in contrast to the direct effect (.26) in the original model, the effect was negative. On the other hand, there was an indirect effect (.36) of expected outcomes on habit strength. This indirect effect was especially mediated through self-reactive outcomes and deficient self-regulation (see Figure 1). Finally, H11 was fully supported with a direct effect of self-reactive outcomes on deficient self regulation (.66), but no indirect effect (.00).

\section{Discussion}

With the exception of $\mathrm{H} 3$ and H10, the original hypothesized causal relationships (LaRose and Eastin, 2004: 364-366) could not be rejected in this study. Subject to the decision to accept or reject the model, the coefficients of the estimated parameters in $\mathrm{H} 3$ and $\mathrm{H} 10$ have to be discussed considering a possible violation of nomological validity (Fritz, 1992). An explanation to why the effect of deficient Internet self-regulation was negative (H3) in contrast to the original study might be speculative. Possibly, the difference resulted from the operationalization which was too weak. Further research should use more powerful items, although the problem of negative connotation is still apparent. A final conclusion on $\mathrm{H} 3$ based on the present data is not possible.

Also in contrast to the original study is the negative direct effect of expected outcomes on habit strength (H10). However, this is not a principle conflict with SCT and U and G; both theories propose that a stronger habitualization leads to a diminishing consciousness of expected outcomes, respectively gratifications. Habitualization is an individual process where in the beginning of habitualization an increase of habitualization should lead to an increasing consciousness of expected outcomes. Once more strongly habitualized, further increase of habitualization should lead to a decreasing consciousness of expected outcomes. Therefore, a more precisely prediction of the correlation between expected outcomes and habitualization depends on the stage of individual habitualization of the user. Further research should therefore investigate 
more in depth the correlation between the level of individual habitualization and the consciousness of expected outcomes. However, this would require a longitudinal research design. Another possibility would be an operationalization of habitualization that is more separated from active, target-oriented media usage (e. g., 'I use the Internet because it's a habit, even when I'm not looking for something special'). According to the nomological validity criteria, the overall model is 'accepted under reserve' (Fritz, 1992: 143).

Because of the reported measurement problems of expected outcomes, extended item batteries should be developed more specifically for a German context. To obtain more discriminant validity between social and status outcomes, a stronger operationalization of status outcomes is needed. Likewise, a stronger operationalization of monetary outcomes is needed.

In sum, the replication of the original study by Larose and Eastin (2004) on Internet usage validates the model of media attendance within a German context under reserve. The results of this study demonstrate that the proposed connection between $\mathrm{U}$ and $\mathrm{G}$ and SCT combined in the model of media attendance is promising, especially the direct integration of habit strength.

A separate test of the causal relationship between the expected outcomes $\left(2^{\text {nd }}\right.$ order) and Internet usage showed that without integration of habit strength, the direct causal connection between expected outcomes and Internet usage is overestimated (standardized effect .31 instead of .23). Furthermore, a direct integration of habitualization and expected outcomes in a single model leads to an overestimation of the causal effect of expected outcomes to habitualization, if at the same time deficient self-regulation has not been added to the model. It was demonstrated that parts of this effect resulted from indirect connections when integrating deficient self-regulation.

Overall, the structural model explains $19 \%$ of Internet usage variance, which is lower compared to the $42 \%$ explained variance found in the original study (LaRose and Eastin, 2004). In the original study, Maximum Likelihood estimation was applied, which assumes a multi-normal distribution. Because of the presence of outliners in the distribution of the dependent variable Internet usage, Larose and Eastin applied a $\log 10(1+$ value $)$ transformation. However, this logarithmic transformation could cause an over-interpretation of the differences between the characteristics of the variables in the lower area. Therefore, a logarithmic transformation was not applied in the present study, although an inspection of the distribution of the dependent variable revealed the presence of outliners. The ULS estimation applied in the present study did not 
assume a normal distribution. An examination of the effect of using a logarithmic transformation in the present study revealed an explained Internet usage variance of $32 \%$.

\section{An examination of the model of media attendance within the context of mobile communication technology in the Netherlands}

The findings of the replication of the original study (Larose and Eastin, 2004) confirm the validity of the model of media attendance within a European context, and also support the hypothesized causal relationships. To also empirically examine the merits of the model of media attendance (LaRose and Eastin, 2004) when applied in a different context of media use, we adapted the instrument to explain Internet usage in the context of mobile communication technology, i. e., the usage of General Packet Radio Services (GPRS). With the use of GPRS, all kinds of extra mobile services become available on a mobile phone, such as sending and receiving full-color pictures, sending and receiving e-mail, or even Internet facilities. A Dutch telecommunications company offers a special subscription for 'closed-user groups', mainly focussing on university personnel and students. Subscription to the closed-user group has special benefits compared with subscriptions from other telecommunications companies. Subscribers pay a very small monthly fee, calling within the closed-user group is free of charge up to 60 hours a month, and a GPRS bundle of 1 megabyte (MB) is also free. Although the closed-user group subscription is an enormous success in terms of number of people who subscribe to this service, GPRS usage is very low. Subscribers do not use this extra mobile service via GPRS, despite the free GPRS bundle.

\section{Method: Sample and procedures}

Subscribers of a telecommunications company in the Netherlands ( $\mathrm{n}=$ 2563) were invited via e-mail to participate in the online survey from 4 June 2004 until 28 June 2004. A total of 474 participants completed the online survey, consisting of $23.9 \%(\mathrm{n}=123)$ GPRS users and $75.1 \%(\mathrm{n}$ $=351$ ) non-GPRS users. There was a significant difference between users and non-users and gender $\left(\chi^{2}(1)=47.48, p<.001\right)$. Of the GPRS users, $91.9 \%$ were male and $8.1 \%$ were female. Of the non-users, $57.8 \%$ were male and $42.2 \%$ female. There was a significant effect of age on users and non-users $(\underline{t}[265]=-2.79, p<.01)$. Age ranged from 17 to 70 years. The mean age of users was 23.1 year $(S D=6.4)$ and the mean age of non-users was 25.2 year $(S D=8.9)$. There was no significant difference between users and non-users and education. 


\section{Measurement}

The original items by LaRose and Eastin (2004) collected from prior $\mathrm{U}$ and $\mathrm{G}$ studies, rephrased as outcomes expectations and classified into six SCT incentive categories (activity, monetary, novel, social, self-reactive, and status), and the original measurement of habit strength, selfregulation, and self-efficacy were rephrased and pre-tested in the context of mobile communication technology. The measurement of the original habit strength scale was not feasible within the group of non-GPRS users. Therefore, habit strength was rephrased by a measure of ownership and use of other information and communication technology (ICTs) such as PDAs, notebooks, digital video cameras, DVD players, game consoles, the Internet, and e-mail. A measure of mobile telephone experience was computed by asking the number of years and months it had been since the participants had first started using a mobile phone. The dependent GPRS usage variable was computed by asking whether the participant made use of GPRS. One open-ended question was included in the survey to ask the respondents to comment why they do or do not use GPRS. From the theory of diffusion of innovations (Rogers, 2003) we know that adoption is also affected by technological features, such as relative advantage, compatibility, complexity, and possibilities to try and observe technological features (Carlsson, Hyvönen, Repo, and Walden, 2005). Therefore, four medium measures (screen legibility, screen size, ease of use, and extensiveness of mobile phone) were additionally included in the survey.

\section{Results}

Table 5 summarizes the means and standard deviations of the model of media attendance measures and GPRS usage. GPRS users differed significantly from non-users for all incentive categories, except for monetary. For all incentive categories, the mean scores of GPRS users were higher than the mean scores for non-users. GPRS users differed significantly from non-users for self-efficacy $(U=14663.50, p<.001)$. The mean score of GPRS users for self-efficacy was higher than the mean score for non-users. The Cronbach's alpha for self-regulation was not reliable $(\alpha=.51)$. Therefore, self-regulation was excluded from further analysis. There was no significant difference between GPRS users and non-users with respect to mobile phone experience $(\underline{t}[472]=.468, p=$ .64). A significant difference was found between users and non-users and the ownership and use of other ICTs $(\underline{t}[472]=-8.69, p<.001)$. The GPRS users owned and used more information and communication technologies than non-users, with exception of Internet and e-mail. The mean score for GPRS use was 2.8 times a week. 
Table 5. Means and standard deviations of the model of media attendance measures and GPRS usage.

\begin{tabular}{|c|c|c|c|c|c|}
\hline & \multicolumn{2}{|c|}{ Users $(N=123)$} & \multicolumn{2}{|c|}{ Non-users $(N=351)$} & \multirow[t]{2}{*}{ Cronbach's $\alpha$} \\
\hline & $M$ & $S D$ & $M$ & $S D$ & \\
\hline Activity $^{1}$ & 2.80 & .79 & $2.58^{*}$ & .89 & .87 \\
\hline Monetary ${ }^{1}$ & 3.43 & .76 & 3.29 & .80 & .71 \\
\hline Novel $^{1}$ & 2.93 & .69 & $2.75^{* * *}$ & .75 & .65 \\
\hline Social $^{1}$ & 3.10 & .69 & $2.90 *$ & .77 & .74 \\
\hline Self-reactive $^{1}$ & 2.59 & .82 & $2.25 * * *$ & .83 & .80 \\
\hline Status ${ }^{1}$ & 2.85 & .74 & $2.48 * * *$ & .67 & .73 \\
\hline Self-efficacy ${ }^{1}$ & 4.61 & .47 & $4.34 * * *$ & .54 & .73 \\
\hline Self-regulation ${ }^{1}$ & - & - & - & - & .51 \\
\hline Experience (years) ${ }^{2}$ & 4.12 & 1.45 & 4.19 & 1.23 & \\
\hline 'Habit' strengh ${ }^{2,3}$ & 4.75 & 1.50 & $3.50 * * *$ & 1.33 & \\
\hline GPRS use (weekly) & 2.80 & 5.23 & - & - & \\
\hline
\end{tabular}

Note: ${ }^{1}$ Scale of one to five $\left(1=\right.$ not at all, $5=$ exactly), Mann Whitney $U:{ }^{*} p<.05$, $* * p<.01, * * * p<.001$

${ }^{2}$ Independent T-Test: $* * * p<.001$

${ }^{3}$ The original habit strength measure is rephrased in ownership and use of other ICTs

GPRS use $(1=$ no, $2=$ yes $)$ was regressed using a binary logistic regression. The total variance explained for GPRS use (Nagelkerke $R^{2}$ ) was $67 \%$. Hosmer and Lemeshow's Goodness-of-Fit Test $\left(\chi^{2}(8)=\right.$ $13.334, p=.101)$ indicated that the logistic model had a good fit $(p>$ .05 ). The model had no homoscedasticity; the model was able to correctly classify $93.2 \%$ of GPRS users and $61.8 \%$ of non-users, with an overall success rate of $85 \%$. Demographics accounted for $39 \%$ of the variance $\left(\chi^{2}(3)=164.739, p<.001\right)$. Gender $(\operatorname{Exp}(B)=.107)$ was a significant predictor. Inverting the odds ratio for gender indicates that when all other variables are held constant, a woman is 9.35 times more likely to not use GPRS than a man is. The model of media attendance measures explained $17 \%$ of the variance $\left(\chi^{2}(9)=94.583, p<.001\right)$. None of the incentive category measures were significant predictors. Selfefficacy $(\operatorname{Exp}(B)=2.106)$, ownership and use of other ICTs $(\operatorname{Exp}(B)=$ $1.352)$, and prior mobile phone experience $(\operatorname{Exp}(B)=.704)$ were significant predictors. The odds ratio for self-efficacy revealed that when holding all other variables constant, for each one-point increase on the fivepoint self-efficacy scale, the odds for using GPRS increase by a multiplicative factor of 2.11. The odds ratio for ownership and use of other ICTs indicated that when holding all other variables constant, the odds for using GPRS increase by a multiplicative factor of 1.35 when people own and use more other ICTs. Inverting the odds ratio for prior mobile 
phone experience indicated that, when holding all other variables constant, the odds for not using GPRS increase by a multiplicative factor of 1.42 when people have more mobile phone experience. The remaining $11 \%$ variance was explained by medium variables $\left(\chi^{2}(4)=68.107, p<\right.$ $.001)$. Extensiveness of mobile phone $(\operatorname{Exp}(B)=1.793)$ was a significant predictor. The odds ratio for extensiveness of mobile phone indicated that, when holding all other variables constant, the odds for using GPRS increase by a multiplicative factor of 1.42 when a mobile phone has more advanced features.

\section{Discussion}

The results of this study showed a remarkably high percentage of explained variance in GPRS usage compared to previous $U$ and $G$ studies on mobile communication technology use (e.g., Dimmick, Kline, and Stafford, 2000; Leung and Wei, 2000). This finding might support the theoretical proposition of the model of media attendance, that prospective measures from a social cognitive perspective would have a larger explanatory power of variance in media use than the retrospective selfreport measures often used in $\mathrm{U}$ and $\mathrm{G}$ studies. However, none of the six incentive categories reconstructed as outcome expectations were significant predictors of GPRS usage. The most significant predictor from the model of media attendance measures was self-efficacy. Hofstetter et al. (2001) stated that self-efficacy involves a combination of expected outcomes of a task with the belief that one can perform a task adequately. This may partly explain why none of the six incentive categories were significant predictors of GPRS usage. GPRS users apparently have low outcome expectancies of GPRS, despite the high levels of self-efficacy about the belief that they know how to make use of GPRS services. This is also reflected in the mean scores of the incentive categories measures. Although GPRS users had higher scores on the six incentives categories than non-GPRS users, the means of the GPRS use incentive categories do not indicate that GPRS users are very pronounced in expressing their use of GPRS into the six incentive categories reconstructed as outcome expectations. The use of GPRS is almost insignificant, i. e., the average use was less than three times a week. According to the open-ended question, respondents did not seem to have a need for GPRS; i. e., it cannot compete with already existing media such as the Internet and e-mail via personal computers. Apparently, the technology and features of GPRS are not a sufficient driver for GPRS services; a missing element of GPRS services is that it does not add value to people's mobile communication needs. According to LaRose and Eastin (2004) active selection of media that best meet personal needs (i. e., outcome expectancies) is not the sole 
mechanism that explains media attendance. Self-efficacy beliefs about one's ability to utilize alternative media channels also contribute to media selection. Active selection dominates when new media alternatives appear or when personal routines are disrupted. But once habits are established, users no longer think whether one alternative or another is a better way of obtaining a particular outcome (Larose and Eastin, 2004). This may also explain the apparent contradiction that the odds for not using GPRS increased when people had more mobile phone experience, although there was no significant difference between GPRS user and non-users on mobile phone experience. Because of the insignificance of GPRS services as an alternative media channel, there is no need for GPRS users to adjust their normal mobile communication behavior based on the experience that their current mobile phone use perfectly fulfils their mobile communication needs.

By far the most variance of GPRS use is explained by demographics, with gender as the most powerful predictor. Within SCT, demographic differences are, according to LaRose and Eastin (2004), attributed to explanatory variables (e.g., men have higher GPRS self-efficacy due to the nature of their past experiences with other ICTs). From the theory of diffusion of innovations (Rogers, 2003) it is known that socio-economic characteristics such as age, education, and social status influence adoption. A secondary analysis of our data indicated no significant differences between male and female GPRS users in relation to the model of media attendance measures. Further empirical research should investigate more in depth the role of gender in media usage to better understand whether gender is a direct predictor of media usage or that gender is fully attributed to explanatory variables of media usage.

Clearly, this study has some limitations. First, the instrument by LaRose and Eastin (2004) is translated from English to Dutch and adjusted to another context of media use. Furthermore, the Cronbach's alpha for self-regulation was not reliable. This could have influenced the results of this study. As this study was a first attempt to apply the model of media attendance to another context of media use, more research is needed to further empirically examine the merits of the model of media attendance applied in different contexts of media use.

\section{General discussion}

Both studies explored LaRose and Eastin's (2004) model of media attendance, within a European context. This extended the $\mathrm{U}$ and $\mathrm{G}$ paradigm within the framework of SCT by instituting new operational measures of gratifications sought reconstructed as outcome expectations. The rep- 
licated model of media attendance within a German context demonstrated that the proposed relation between $\mathrm{U}$ and G and SCT is a fruitful one, especially because of the direct integration of habit strength. Without this integration, the direct causal connection between expected outcomes and Internet usage could be overestimated. Furthermore, a direct integration of habitualization and expected outcomes in a single model leads to an overestimation of the direct causal effect of expected outcomes to habitualization. It was demonstrated that parts of this effect result from indirect connections when integrating self-efficacy and deficient self-regulation. In further studies, the operationalization of expected outcomes should be modified to increase the level of discrimant validity. Furthermore, the present study made clear that a more in-depth investigation of the role of habitualization in the process of media usage is needed.

An examination of the model within the context of mobile communication technology in The Netherlands indicated that the model is applicable to other contexts of media use, although the significance of outcome expectancies was not fully supported. Also, the role of demographics as proposed to being attributed to explaining variables in the model should be clarified, as gender was a strong direct predictor of media usage. Interesting is also the significance of technological features of a medium to explain media usage. This might indicate that besides outcome expectations, the technological features of a new media technology itself are also important in explaining media usage, instead of only the incentive to be expected when using new media technology. This is in accordance with the three basic tenets of SCT. To predict future use of new media technology requires that potential users should have the possibility to try (enactive learning) or observe (vicarious learning) the new media technology. There also may be a reciprocal relationship between self-efficacy and outcome expectations. Further research should explore this possible reciprocal relationship more in depth.

The findings of both the validation of the original model and the examination of the model in another context of use indicate that the proposed values of the new variables from SCT reconstructed as outcome expectations improve the explanatory power of gratifications, and with that support the findings of the study by LaRose and Eastin (2004) that the new model of media attendance within the framework of SCT both affirm the $\mathrm{U}$ and $\mathrm{G}$ paradigm and extend it to a theory of media attendance grounded in SCT. The present study suggests some interesting ideas for further research to improve the model of media attendance (e. g., the role of gender, habitualization). The findings of this study show that the model of media attendance, grounded in both $U$ and $G$ and $\mathrm{SCT}$, is a promising step forward in measuring media selectivity and 
usage, both from the perspective of explained media usage and from the perspective of validating and extending theory. As new technologies present people with more and more media choices, motivation and satisfaction become even more crucial components of audience analysis (Ruggiero, 2000). The need for alternative measurement and analysis is needed to better understand people's needs and desires, which is vital to be able to offer them products and services that they will actually use.

\section{Note}

1. The original German items will be reported in Rickes, Linke, and Criegern (2006).

\section{References}

Babrow, A. S. (1988). Theory and method in research on audience motives. Journal of Broadcasting and Electronic Media, 32(4), 471-487.

Babrow, A. S. and Swanson, D. L. (1988). Disentangling antecedents of audience exposure levels: Extending expectancy-value analyses of gratifications sought from television news. Communication Monographs, 55, 1-21.

Backhaus, K. (Ed.). (2003). Multivariate Analysemethoden. Eine anwendungsorientierte Einführung [Multivariate analysis methods. An application-oriented introduction] $\left(10^{\text {th }}\right.$ ed.). Berlin: Springer.

Bagozzi, R. and Yi, Y. (1988). On the evaluation of structural equation models. Working paper, University of Michigan.

Bandura, A. (1986). Social foundations of thought and action: A social cognitive theory. Englewood Cliffs, NJ: Prentice Hall.

Bandura, A. (1991). Social cognitive theory of self-regulation. Organizational Behavior and Human Decision Processes, 50, 248-287.

Bandura, A. (1997). Self-efficacy: The exercise of control. New York: Freeman.

Bandura, A. (2002). Social cognitive theory of mass communication. In J. Bryant and D. Zillman (Eds.), Media effects: Advances in theory and research (2nd ed., pp. 121-155). Mahwah, NJ: Erlbaum.

Carlsson, C., Hyvönen, K., Repo, P., and Walden, P. (2005). Asynchronous adoption patterns of mobile services. Proceedings of the $38^{\text {th }}$ International Conference on System Sciences, IEEE, HI, 2005.

Dimmick, J., Kline, S., and Stafford, L. (2000). The gratification niches of personal e-mail and the telephone: Competition, displacement, and complementarity. Communication Research, 27(2), 227-248.

Fornell, C., Tellis, G. J., and Zinkhan, G. M. (1982). Validity assessment: A structural equations approach using partial least squares. In B. Walker (Ed.), An assessment of marketing thought and practice (pp. 405-409). Chicago, IL: American Marketing Association.

Fritz, W. (1992). Marktorientierte Unternehmensführung und Unternehmenserfolg: Grundlagen und Ergebnisse einer empirischen Untersuchung [Market-oriented management and company success: bases and results of an empirical research]. Stuttgart: Schäffer-Poeschel.

Greenberg, B. (1974). Gratfications of television viewing and their correlates for British children. In J. G. Blumler and E. Katz (Eds.). The uses of mass communication. Beverly Hills, CA: Sage. 
Hofstetter, C. R., Zuniga, S., and Dozier, D. M. (2001). Media self-efficacy: Validation of a new concept. Mass communication and Society, 4(1), 61-78.

Hendriks Vettehen, P. G., Van Snippenburg, L. B. (2002). Measuring motivations for media exposure: A thesis. Quality and Quantity, 36(3), 259-276.

Katz, E., Blumler, J. G., and Gurevitch, M. (1974). Utilization of mass communication by the individual. In J. G. Blumler and E. Katz (Eds.), The uses of mass communication. Beverly Hills, CA: Sage.

LaRose, R. (1998). Understanding personal telephone behavior. In H. Sawhney and G. Barnett (Eds.), Progress in communication science, Vol. XV: Advances in telecommunications (pp. 1-27). Stamford, CT: Ablex.

LaRose, R., Mastro, D. A., and Eastin, M. S. (2001). Understanding Internet usage: A social cognitive approach to uses and gratifications. Social Science Computer Review, 19, 395-413.

LaRose, R., Lin, C. A., and Eastin, M. S. (2003). Unregulated Internet usage: Addiction, habit, or deficient self-regulation? Media Psychology, 5(3), 224-253.

LaRose, R. and Eastin, M. S. (2004). A social cognitive theory of Internet uses and gratifications: Toward a new model of media attendance. Journal of Broadcasting and Electronic Media, 48(3), 358-377.

Leung, L. and Wei, R. (2000). More than just talk on the move: Uses and gratifications of the cellular phone. Journalism and Mass Communication Quarterly, 77(2), $308-320$.

Lometti, G. E., Reeves, B., and Bybee, C. R. (1977). Investigating the assumptions of uses and gratifications research. Communication Research, 4, 321-338.

Messaris, P. (1977). Biases of self-reported 'functions' and 'gratifications' of mass media use. A review of general semantics, 34, 316-329.

McQuail, D. (1994). The rise of media of mass communication. In D. McQuail (Ed.), Mass communication theory: An introduction (pp. 1-29). London: Sage.

McQuail, D. (2001). With more hindsight: Conceptual problems and some ways forward for media use research. Communications: The European Journal of Communication Research, 26(4), 337-350.

Opp, K. D. (2002). Methodologie der Sozialwissenschaften. Einführung in die Probleme ihrer Theoriebildung und praktischen Anwendung [The methodology of social sciences. Introduction into the problems of theory-building and their practical application] ( $5^{\text {th }}$ revised ed.). Wiesbaden: Westdeutscher Verlag.

Palmgreen, P., Wenner, L., and Rosegren, K. (1985). Uses and gratifications research: The past ten years. In K. Rosegren, L. Wenner, and P. Palmgreen (Eds.), Media gratifications research (pp. 11-37). Beverly Hills, CA: Sage.

Peters, O. and Ben Allouch, S. (2005). Always connected: A longitudinal field study of mobile communication. Telematics and Informatics, 22(3), 239-256.

Popper, K. R. (1989). Logik der Forschung [The logic of research] ( $9^{\text {th }}$ revised ed.). Tübingen: Mohr.

Rickes, M., Linke, J., and Criegern, C. von (2006). Aktive Mediennutzung und Habitualisierung. Beitrag der sozial-kognitiven Theorie Banduras zur Integration beider Konzepte [Active media use and habitualization. The contribution of Bandura's social cognitive theory in integrating both concepts]. Manuscript in preparation.

Rogers, E. M. (2003). Diffusion of Innovations (5th ed.). New York: Free Press.

Rosegren, K. E. (1974). Uses and gratifications: A paradigm outlined. In J. G. Blumler and E. Katz (Eds.), The uses of mass communication. Beverly Hills, CA: Sage.

Ruggiero, T. E. (2000). Uses and gratifications theory in the $21^{\text {st }}$ century. Mass Communication and Society, 3(1), 3-37.

Stone, D. (1998). Social cognitive theory. Available (consulted 30 January 2006) at: www.med.usf.edu/ kmbrown/Social_Cognitive_Theory_Overview.htm 


\section{Appendix: Additional tables}

Additional table 1. Measurement of exogenous variables - expected outcomes.

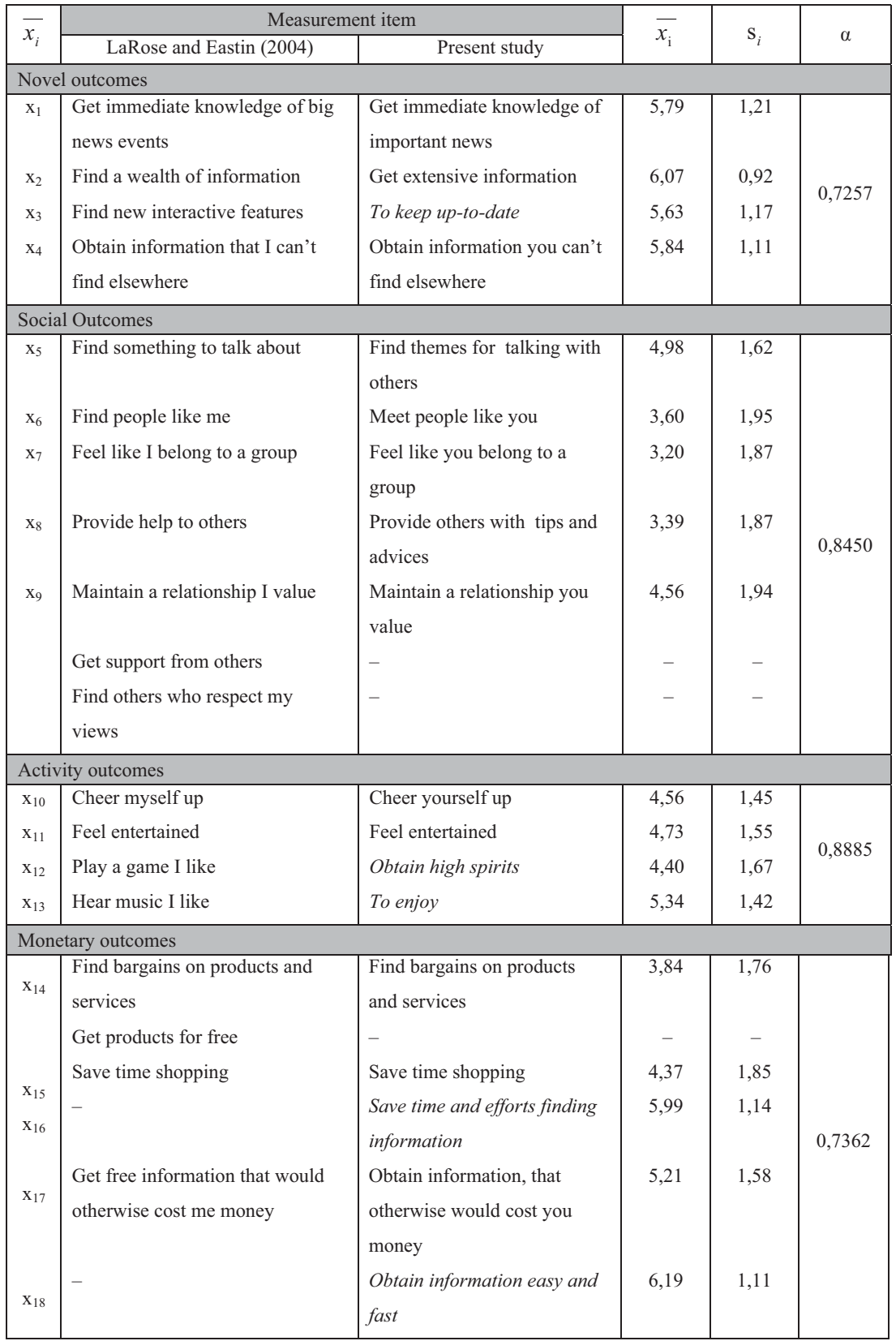


Additional table 1. continued.

\begin{tabular}{|c|c|c|c|c|c|}
\hline \multicolumn{6}{|c|}{ Self-reactive outcomes } \\
\hline $\mathrm{x}_{19}$ & Relieve boredom & Relieve boredom & 4,74 & 1,96 & \multirow{6}{*}{0,8829} \\
\hline $\mathrm{x}_{20}$ & Find a way to pass the time & To kill time & 4,79 & 1,97 & \\
\hline $\mathrm{x}_{21}$ & - & $\begin{array}{l}\text { To distract you from stressful } \\
\text { situations }\end{array}$ & 3,96 & 1,87 & \\
\hline $\mathrm{x}_{22}$ & Feel less lonely & Feel less lonely & 2,97 & 1,88 & \\
\hline $\mathrm{x}_{23}$ & Forget my problems & To get away from it all & 3,44 & 1,78 & \\
\hline $\mathrm{x}_{24}$ & Feel relaxed & Feel relaxed & 4,39 & 1,61 & \\
\hline \multicolumn{6}{|c|}{ Status outcomes } \\
\hline $\mathrm{x}_{25}$ & $\begin{array}{l}\text { Get up to date with new } \\
\text { technologies }\end{array}$ & $\begin{array}{l}\text { Get up to date with new } \\
\text { technologies }\end{array}$ & 4,60 & 1,60 & \multirow{5}{*}{0,8800} \\
\hline $\mathrm{x}_{26}$ & $\begin{array}{l}\text { Find others who respect my } \\
\text { views }\end{array}$ & $\begin{array}{l}\text { Find people who respect your } \\
\text { views }\end{array}$ & 3,46 & 1,86 & \\
\hline $\mathrm{x}_{27}$ & Provide help to others & $\begin{array}{l}\text { To give proof of your } \\
\text { knowledge and qualifications } \\
\text { when helping other people }\end{array}$ & 3,77 & 1,77 & \\
\hline $\mathrm{x}_{28}$ & Find people like me & $\begin{array}{l}\text { Find people, holding your } \\
\text { competence in high regard }\end{array}$ & 3,32 & 1,81 & \\
\hline $\mathrm{x}_{29}$ & $\begin{array}{l}\text { Improve my future prospects in } \\
\text { life }\end{array}$ & $\begin{array}{l}\text { Find people, confirming your } \\
\text { positions and opinions }\end{array}$ & 4,05 & 1,54 & \\
\hline
\end{tabular}

Note. Items in italics differ more from the original items or are additional. 
Additional table 2. Measurement of endogenous variables.

\begin{tabular}{|c|c|c|c|c|c|}
\hline \multirow{2}{*}{$\overline{y_{i}}$} & \multicolumn{2}{|c|}{ Measurement item } & \multirow{2}{*}{$\overline{y_{i}}$} & \multirow{2}{*}{$s_{i}$} & \multirow{2}{*}{$\alpha$} \\
\hline & LaRos and Eastin (2004) & Present study & & & \\
\hline \multicolumn{6}{|c|}{ Habit strength } \\
\hline $\mathrm{y}_{1}$ & $\begin{array}{l}\text { The Internet is part of my usual } \\
\text { routine }\end{array}$ & $\begin{array}{l}\text { Internet usage is part of my } \\
\text { usual routine }\end{array}$ & 6,50 & 0,97 & \\
\hline $\mathrm{y}_{2}$ & $\begin{array}{l}\text { I find myself going online about } \\
\text { the same time each day }\end{array}$ & $\begin{array}{l}\text { I find myself going online } \\
\text { about the same time each day }\end{array}$ & 4,30 & 1,99 & \\
\hline $\mathrm{y}_{3}$ & $\begin{array}{l}\text { I would miss the Internet if I } \\
\text { could no longer go online }\end{array}$ & $\begin{array}{l}\text { I would miss the internet if it } \\
\text { would not be available }\end{array}$ & 6,21 & 1,18 & 0,7335 \\
\hline $\mathrm{y}_{4}$ & - & $\begin{array}{l}\text { I could not imagine that } \\
\text { internet usage is not any } \\
\text { longer part of my everyday } \\
\text { life }\end{array}$ & 6,08 & 1,16 & \\
\hline \multicolumn{6}{|c|}{ Self-efficacy } \\
\hline $\mathrm{y}_{5}$ & $\begin{array}{l}\text { I feel confident understanding } \\
\text { terms/words relating to Internet } \\
\text { hardware }\end{array}$ & $\begin{array}{l}\text { I'm able to describe terms } \\
\text { and words relating to Internet } \\
\text { hardware }\end{array}$ & 5,29 & 1,44 & \\
\hline $\mathrm{y}_{6}$ & $\begin{array}{l}\text { I feel confident explaining why a } \\
\text { task will not run on the Internet }\end{array}$ & $\begin{array}{l}\text { I'm able to explain why a } \\
\text { task will not run on the } \\
\text { Internet }\end{array}$ & 4,57 & 1,71 & \\
\hline $\mathrm{y}_{7}$ & $\begin{array}{l}\text { I feel confident understanding } \\
\text { terms/words relating to Internet } \\
\text { software }\end{array}$ & $\begin{array}{l}\text { I'm able to understand terms } \\
\text { and words relating to Internet } \\
\text { software }\end{array}$ & 5,20 & 1,46 & 0,9173 \\
\hline $\mathrm{y}_{8}$ & $\begin{array}{l}\text { I feel confident using the Internet } \\
\text { to gather data }\end{array}$ & $\begin{array}{l}\text { Internet usage don't poses a } \\
\text { challenge for me }\end{array}$ & 5,91 & 1,53 & \\
\hline $\mathrm{y}_{9}$ & $\begin{array}{l}\text { I feel confident describing } \\
\text { functions of Internet hardware }\end{array}$ & $\begin{array}{l}\text { I'm able to describe } \\
\text { functions of Internet } \\
\text { hardware }\end{array}$ & 4,60 & 1,73 & \\
\hline $\mathrm{y}_{10}$ & $\begin{array}{l}\text { I feel confident trouble shooting } \\
\text { Internet problems }\end{array}$ & $\begin{array}{l}\text { I'm able to resolve problems } \\
\text { relating to Internet usage } \\
\text { independently }\end{array}$ & 5,04 & 1,55 & \\
\hline \multicolumn{6}{|c|}{ Deficient self-regulation } \\
\hline $\mathrm{y}_{11}$ & $\begin{array}{l}\text { I have to keep using the Internet } \\
\text { more and more to get my thrill }\end{array}$ & $\begin{array}{l}\text { It is annoying if I can't use } \\
\text { the Internet for a longer time }\end{array}$ & 5,02 & 1,78 & \\
\hline $\mathrm{y}_{12}$ & $\begin{array}{l}\text { I get tense, moody, or irritable if I } \\
\text { can't get on the Web when I want }\end{array}$ & $\begin{array}{l}\text { I feel bad if I can't get on the } \\
\text { Internet when I want }\end{array}$ & 4,07 & 1,85 & \\
\hline $\mathrm{y}_{13}$ & $\begin{array}{l}\text { I have a hard time keeping my } \\
\text { Internet use under control }\end{array}$ & $\begin{array}{l}\text { I have the feeling that I miss } \\
\text { out on something if I am not } \\
\text { online }\end{array}$ & 3,59 & 1,84 & 0,7677 \\
\hline
\end{tabular}


Additional table 2. continued.

\begin{tabular}{|c|c|c|c|c|c|}
\hline $\mathrm{y}_{14}$ & $\begin{array}{l}\text { I have tried unsuccessfully to cut } \\
\text { down on the amount of time I } \\
\text { spend online } \\
\text { I sometimes try to conceal how } \\
\text { much time I spend online from } \\
\text { my family or friends } \\
\text { I would go out of my way to } \\
\text { satisfy my Internet urges } \\
\text { I feel my Internet use is out of } \\
\text { control }\end{array}$ & $\begin{array}{l}\text { I have tried to cut down on } \\
\text { the amount of time I spend } \\
\text { online but it is difficult } \\
\text { - } \\
\text { - }\end{array}$ & 2,34 & 1,59 & \\
\hline \multicolumn{6}{|c|}{ Internet experience } \\
\hline $\mathrm{y}_{15}$ & $\begin{array}{l}\text { Internet experience } \\
\text { (years) }\end{array}$ & $\begin{array}{l}\text { Internet experience } \\
\text { (years) }\end{array}$ & 7,22 & 2,75 & - \\
\hline \multicolumn{6}{|c|}{ Internet usage } \\
\hline $\mathrm{y}_{16}$ & $\begin{array}{l}\text { Average daily internet usage } \\
\text { (minutes) }\end{array}$ & $\begin{array}{l}\text { Average daily internet usage } \\
\text { (minutes) }\end{array}$ & 179,70 & 190,84 & - \\
\hline
\end{tabular}

Note. Items in italics differ more from the original items or are additional. 
Additional table 3. Confirmatory factor analysis of the measurement model ( $1^{\text {st }} \mathrm{order}$ ).

\begin{tabular}{|c|c|c|c|}
\hline & & Factor loading & Squared multiple correlation \\
\hline & $\mathrm{x}_{1}$ & 0,49 & 0,24 \\
\hline & $\mathrm{x}_{2}$ & 0,63 & 0,40 \\
\hline$\stackrel{\mathscr{\Xi}}{\Xi}$ & $\mathrm{x}_{3}$ & 0,68 & 0,46 \\
\hline$\stackrel{0}{0}$ & $\mathrm{x}_{4}$ & 0,70 & 0,49 \\
\hline $\bar{d}$ & reliability of construct $\left(\rho_{c}(\xi)>0,6\right)$ & & 0,7217 \\
\hline & average explained variance portion $\left(\rho_{\mathrm{v}}(\xi)>0,5\right)$ & & 0,3974 \\
\hline & convergence validity $\left(\mathrm{M}^{2}>0,4\right)$ & & 0,4472 \\
\hline & $\mathrm{x}_{5}$ & 0,70 & 0,49 \\
\hline & $\mathrm{x}_{6}$ & 0,82 & 0,67 \\
\hline o & $\mathrm{x}_{7}$ & 0,76 & 0,58 \\
\hline हु & $\mathrm{x}_{8}$ & 0,75 & 0,56 \\
\hline$\underline{\Xi}$ & $\mathrm{x}_{9}$ & 0,60 & 0,36 \\
\hline 岁 & reliability of construct $\left(\rho_{c}(\xi)>0,6\right)$ & & 0,8493 \\
\hline & average explained variance portion $\left(\rho_{\mathrm{v}}(\xi)>0,5\right)$ & & 0,5325 \\
\hline & convergence validity $\left(\mathrm{M}^{2}>0,4\right)$ & & 0,4472 \\
\hline & $\mathrm{x}_{10}$ & 0,72 & 0,52 \\
\hline & $\mathrm{x}_{11}$ & 0,75 & 0,56 \\
\hline$\tilde{\Xi}$ & $\mathrm{x}_{12}$ & 0,92 & 0,85 \\
\hline 亏े & $\mathrm{x}_{13}$ & 0,86 & 0,74 \\
\hline$\stackrel{\overrightarrow{3}}{3}$ & reliability of construct $\left(\rho_{c}(\xi)>0,6\right)$ & & 0,8879 \\
\hline 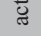 & average explained variance portion $\left(\rho_{\mathrm{v}}(\xi)>0,5\right)$ & & 0,6667 \\
\hline & convergence validity $\left(\mathrm{M}^{2}>0,4\right)$ & & 0,4472 \\
\hline & $\mathrm{x}_{14}$ & - & - \\
\hline & $\mathrm{x}_{15}$ & - & - \\
\hline$\stackrel{\mathscr{\Xi}}{\Xi}$ & $\mathrm{x}_{16}$ & 0,70 & 0,49 \\
\hline$\stackrel{8}{\Xi}$ & $\mathrm{x}_{17}$ & 0,66 & 0,44 \\
\hline$\vec{z}$ & $\mathrm{x}_{18}$ & 0,74 & 0,55 \\
\hline $\bar{\Xi}$ & reliability of construct $\left(\rho_{c}(\xi)>0,6\right)$ & & 0,7428 \\
\hline & average explained variance portion $\left(\rho_{\mathrm{v}}(\xi)>0,5\right)$ & & 0,4911 \\
\hline & convergence validity $\left(\mathrm{M}^{2}>0,4\right)$ & & 0,4472 \\
\hline
\end{tabular}


Additional table 3. continued.

\begin{tabular}{|c|c|c|c|}
\hline \multirow{9}{*}{ 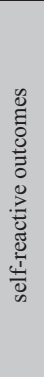 } & $\mathrm{x}_{19}$ & 0,66 & 0,44 \\
\hline & $\mathrm{x}_{20}$ & 0,71 & 0,50 \\
\hline & $\mathrm{x}_{21}$ & 0,72 & 0,52 \\
\hline & $\mathrm{x}_{22}$ & 0,76 & 0,58 \\
\hline & $\mathrm{x}_{23}$ & 0,74 & 0,55 \\
\hline & $\mathrm{x}_{24}$ & 0,86 & 0,74 \\
\hline & reliability of construct $\left(\rho_{\mathrm{c}}(\xi)>0,6\right)$ & \multicolumn{2}{|c|}{0,8809} \\
\hline & average explained variance portion $\left(\rho_{\mathrm{v}}(\xi)>0,5\right.$ & \multicolumn{2}{|c|}{0,5538} \\
\hline & convergence validity $\left(\mathrm{M}^{2}>0,4\right)$ & \multicolumn{2}{|c|}{0,4472} \\
\hline \multirow{8}{*}{ 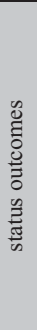 } & $\mathrm{X}_{25}$ & - & - \\
\hline & $\mathrm{x}_{26}$ & 0,89 & 0,79 \\
\hline & $\mathrm{x}_{27}$ & 0,73 & 0,53 \\
\hline & $\mathrm{x}_{28}$ & 0,80 & 0,64 \\
\hline & $\mathrm{X}_{29}$ & 0,79 & 0,62 \\
\hline & reliability of construct $\left(\rho_{c}(\xi)>0,6\right)$ & \multicolumn{2}{|c|}{0,8796} \\
\hline & average explained variance portion $\left(\rho_{\mathrm{v}}(\xi)>0,5\right)$ & \multicolumn{2}{|c|}{0,6473} \\
\hline & convergence validity $\left(\mathrm{M}^{2}>0,4\right)$ & \multicolumn{2}{|c|}{0,4472} \\
\hline
\end{tabular}


Additional table 4. Local measures of the complete model.

\begin{tabular}{|c|c|c|c|}
\hline & & Factor loading & Squared multiple correlation \\
\hline \multirow{7}{*}{ 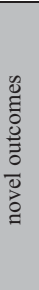 } & $\mathrm{x}_{1}$ & 0,52 & 0,27 \\
\hline & $\mathrm{x}_{2}$ & 0,63 & 0,40 \\
\hline & $\mathrm{x}_{3}$ & 0,67 & 0,45 \\
\hline & $\mathrm{x}_{4}$ & 0,69 & 0,48 \\
\hline & reliability of construct $\left(\rho_{c}(\xi)>0,6\right)$ & \multicolumn{2}{|r|}{0,7235} \\
\hline & average explained variance portion $\left(\rho_{\mathrm{v}}(\xi)>0,5\right)$ & \multicolumn{2}{|r|}{0,3981} \\
\hline & convergence validity $\left(\mathrm{M}^{2}>0,4\right)$ & \multicolumn{2}{|r|}{0,4483} \\
\hline \multirow{8}{*}{ 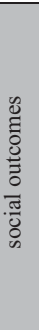 } & $\mathrm{x}_{5}$ & 0,71 & 0,50 \\
\hline & $\mathrm{x}_{6}$ & 0,81 & 0,66 \\
\hline & $\mathrm{x}_{7}$ & 0,76 & 0,58 \\
\hline & $\mathrm{x}_{8}$ & 0,74 & 0,55 \\
\hline & $\mathrm{x}_{9}$ & 0,62 & 0,38 \\
\hline & reliability of construct $\left(\rho_{c}(\xi)>0,6\right)$ & \multicolumn{2}{|r|}{0,8504} \\
\hline & average explained variance portion $\left(\rho_{v}(\xi)>0,5\right)$ & \multicolumn{2}{|r|}{0,5340} \\
\hline & convergence validity $\left(\mathrm{M}^{2}>0,4\right)$ & \multicolumn{2}{|r|}{0,4483} \\
\hline \multirow{7}{*}{ 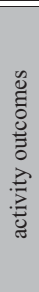 } & $\mathrm{x}_{10}$ & 0,70 & 0,49 \\
\hline & $\mathrm{x}_{11}$ & 0,76 & 0,58 \\
\hline & $\mathrm{x}_{12}$ & 0,93 & 0,86 \\
\hline & $\mathrm{x}_{13}$ & 0,86 & 0,74 \\
\hline & reliability of construct $\left(\rho_{c}(\xi)>0,6\right)$ & \multicolumn{2}{|r|}{0,8883} \\
\hline & average explained variance portion $\left(\rho_{\mathrm{v}}(\xi)>0,5\right)$ & \multicolumn{2}{|r|}{0,6680} \\
\hline & convergence validity $\left(\mathrm{M}^{2}>0,4\right)$ & \multicolumn{2}{|r|}{0,4483} \\
\hline \multirow{6}{*}{ 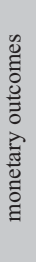 } & $\mathrm{x}_{16}$ & 0,68 & 0,46 \\
\hline & $\mathrm{x}_{17}$ & 0,71 & 0,50 \\
\hline & $\mathrm{x}_{18}$ & 0,69 & 0,48 \\
\hline & reliability of construct $\left(\rho_{c}(\xi)>0,6\right)$ & \multicolumn{2}{|r|}{0,7353} \\
\hline & average explained variance portion $\left(\rho_{\mathrm{v}}(\xi)>0,5\right)$ & \multicolumn{2}{|r|}{0,4809} \\
\hline & convergence validity $\left(\mathrm{M}^{2}>0,4\right)$ & \multicolumn{2}{|r|}{0,4483} \\
\hline \multirow{9}{*}{ 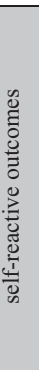 } & $\mathrm{X}_{19}$ & 0,65 & 0,42 \\
\hline & $\mathrm{x}_{20}$ & 0,69 & 0,48 \\
\hline & $\mathrm{x}_{21}$ & 0,67 & 0,45 \\
\hline & $\mathrm{x}_{22}$ & 0,76 & 0,58 \\
\hline & $\mathrm{x}_{23}$ & 0,72 & 0,52 \\
\hline & $\mathrm{x}_{24}$ & 0,81 & 0,66 \\
\hline & reliability of construct $\left(\rho_{c}(\xi)>0,6\right)$ & \multicolumn{2}{|r|}{0,8644} \\
\hline & average explained variance portion $\left(\rho_{\mathrm{v}}(\xi)>0,5\right)$ & \multicolumn{2}{|r|}{0,5166} \\
\hline & convergence validity $\left(\mathrm{M}^{2}>0,4\right)$ & \multicolumn{2}{|r|}{0,4483} \\
\hline
\end{tabular}


Additional table 4. continued.

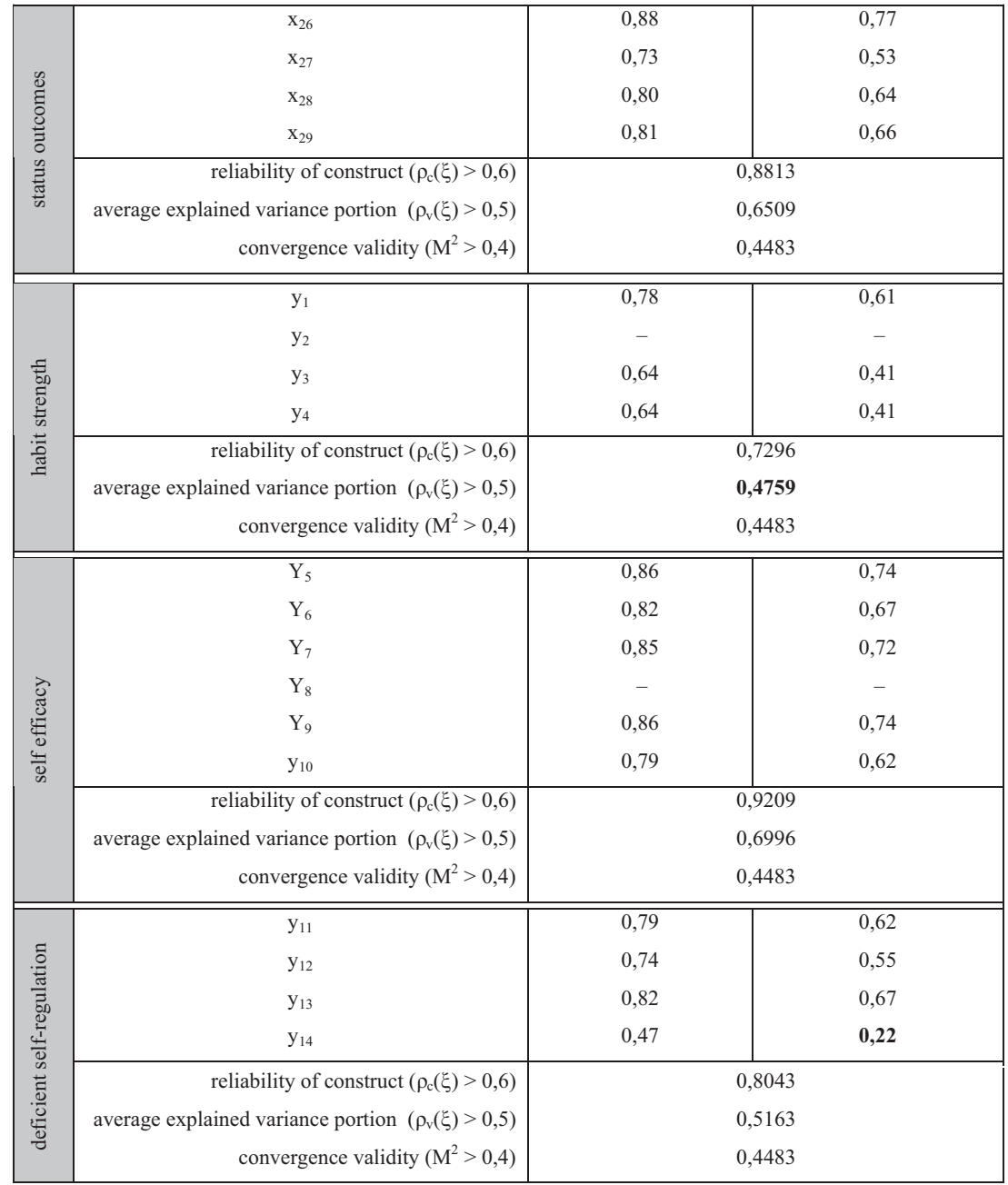

